\title{
NegligenCE, MEdicAl MALPRACTICE, ViCARIOUS LIABILITY, OR PATIENT RESPONSIBILITY: WHO SHOULD Pay When a Patient Contracts MRSA From a HEALTHCARE FACILITY?
}

\author{
Beth A. Barnes*
}

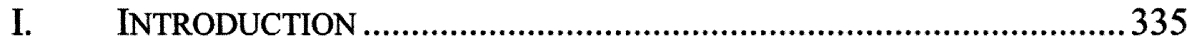

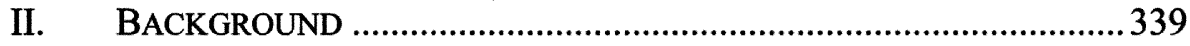

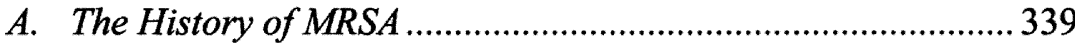

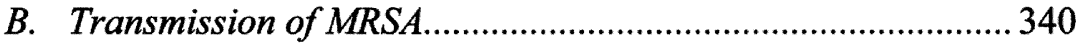

C. MRSA Resistant To Almost All Antibiotics ................................ 341

III. PREVENTATIVE MEASURES THAT WORK AND NEW INSURANCE POLICIES PREVENTING COST-RECOVERY FOR SECONDARY

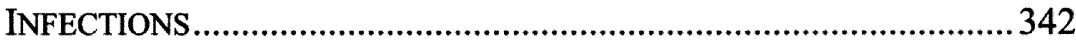

A. Preventative Measures............................................................ 342

B. Medicare/Medicaid and Private Insurance Policies Forbidding Payment of Secondary Infections............................................ 345

C. The Costs to Treat versus the Costs to Prevent MRSA ............. 347

IV. ANALYSIS: WHY FACILITIES SHOULD BE HELD LIABLE UNDER Claims of NEgligenCE, MEDICAL MALPRACTICE, OR VICARIOUS

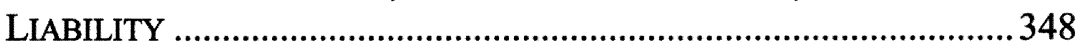

A. The Law in the United States .................................................. 348

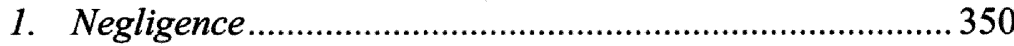

2. Medical Malpractice .........................................................355

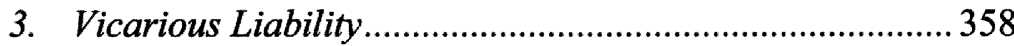

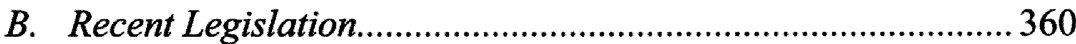

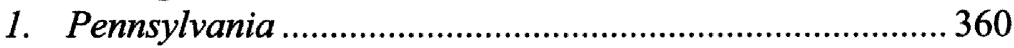

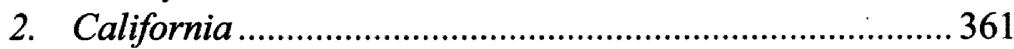

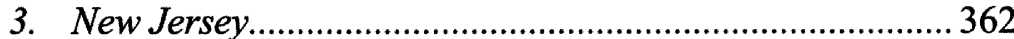

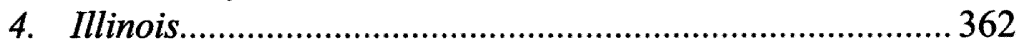

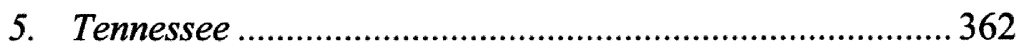

6. New Hampshire, Indiana, District of Columbia, Virginia,

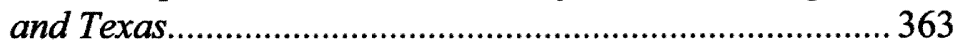

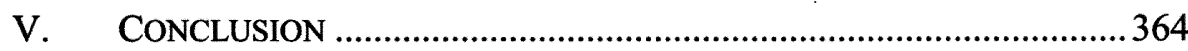

\section{INTRODUCTION}

Envision entering the hospital for a common surgical procedure or illness. While in the hospital you are placed in the same room as a patient who has methicillin-resistant Staphylococcus aureus ("MRSA"), an antibi-

J.D., 2009, Indiana University School of Law - Indianapolis; B.S., 2003, Ball State 
otic-resistant infection. During the course of your treatment, physicians and nurses fail to wash their hands between contact with you and your roommate. After a few days, you acquire an antibiotic-resistant infection and tests reveal it is MRSA. What was supposed to be a short hospital stay has turned into more than three weeks of inpatient care and a lifelong health issue. After discharge from the hospital, you contact an attorney because the hospital wants you to pay for the extended stay. You insist you would not have been hospitalized for more than a few days had you not contracted MRSA while in the hospital. A legal situation arises and courts are faced with determining whether you, your insurance company, or the hospital must foot the bill for the costs associated with the MRSA infection. Your situation is not unique; rather, it is a growing trend in healthcare facilities across the nation.

Each year in the United States thousands of people enter hospitals, long-term care facilities, and other medical centers (hereinafter, "Facilities" or "Facility") for treatment of illness or injury. Patients do not expect to contract an infection while receiving medical care; yet, in recent years, a growing number of patients have contracted nosocomial infections ${ }^{1}$ and become more ill than when they first presented to the Facility. ${ }^{2}$ The Centers for Disease Control and Prevention ("CDC") discovered that each year more than two million healthcare-acquired infections are reported, ${ }^{3}$ which result in over 100,000 deaths. ${ }^{4}$ The CDC also determined that at least onethird of healthcare-acquired infection deaths were preventable. ${ }^{5}$ Facilities are notorious for developing pathogens ${ }^{6}$ because patients bring infections into the Facility then spread these infections to other patients. ${ }^{7}$ These infections often become drug-resistant when the bacteria mutate and become able to defeat currently used antibiotics. ${ }^{8}$ The overuse of antibiotics has made bacteria capable of mutating and becoming drug-resistant. ${ }^{9}$ MRSA is one of these drug-resistant infections and is currently one of the most rampant nosocomial infections in healthcare Facilities worldwide. ${ }^{10}$

1. Nosocomial infection refers to an infection acquired in the Facility that the patient did not have prior to admission. Trisha Torrey, What are Nosocomial Infections?, http://patients.about.com/od/glossary/g/nosocomial.htm (last visited May 7, 2009).

2. David Polin, 43 AM. Jur. ProOf OF Facts 2D $\$ 109$ (2008); Betsy MCCAughey, UnNeCESSARy Deaths: The Human and Financial Costs of Hospital Infections 1 (Committee to Reduce Infection Deaths, 3rd ed. 2008), available at http:// www.hospitalinfection.org/ridbooklet.pdf.

3. Jonathan M. Glauser, Infection Control and the Emergency Department, EMERGENCY MED. REPORTS, October 15, 2007, at 2, available at 2007 WLNR 20428074 (citation omitted).

4. MCCAUGHEY, supra note 2 , at i (citation omitted).

5. Glauser, supra note 3, at 2 (citation omitted).

6. Pathogens are "disease-producing organisms." PoLIN, supra note 2.

7. Id.

8. Id.

9. Id.

10. See Ann Huletsky et al., Identification of Methicillin-Resistant Staphylococcus 
MRSA is a type of staphylococcal ("staph") infection resistant to a number of antibiotics. ${ }^{11}$ MRSA became a problem in Facilities worldwide in the $1960 \mathrm{~s}^{12}$ and the first MRSA infection was reported in the United States in $1968 .{ }^{13}$ Healthcare-acquired or hospital-acquired MRSA ("HAMRSA") cases have one or more of the following patient risk factors: (1) presence of an intravenous line, a catheter, a feeding tube, or other invasive device; (2) prior MRSA infection or colonization ${ }^{14}$; (3) recent antibiotic use; (4) recent or current contact with a Facility including surgery, hospitalization, dialysis, or residence in a long-term care facility within the previous year; or (5) testing MRSA-positive more than forty-eight hours after Facility admission. ${ }^{15}$ HA-MRSA accounts for eighty-five percent of all MRSA infections. ${ }^{16}$ MRSA is spread throughout Facilities when MRSApositive patients are admitted without being tested or isolated. ${ }^{17}$ Facilities generally see an increase in all categories of staph infections once MRSA has been found in a patient already in the Facility. ${ }^{18}$ It logically follows that the sooner MRSA-infected or colonized patients are isolated from other patients the less likely it is for them to spread MRSA.

The presence of MRSA has increased healthcare costs significantly. ${ }^{19}$ Healthcare costs associated with MRSA in the United States alone were around six billion dollars in 2005 , and are increasing each year. ${ }^{20}$ Recent studies have shown that Facilities are capable of controlling the spread of

aureus Carriage in Less Than 1 Hour During a Hospital Surveillance Pragram, 40 CLINICAL INFECTIOUS DISEASES 976, 976 (2005).

11. Centers for Disease Control and Prevention, MRSA in Healthcare Settings [hereinafter MRSA in Healthcare Settings], http://www.cdc.gov/ncidod/dhqp/ar_MRSA_spotlight_2006.html. (last visited March 30, 2010).

12. R. Monina Klevens et al., Invasive Methicillin-Resistant Staphylococcus aureus Infections in the United States, 298 JAMA 1763, 1764 (2007).

13. 3 Hum. Resources Series: Policies \& Practices $\S 219: 21$ (Thomson Reuters/West 2008) [hereinafter HR Series: Policies \& Practices].

14. Colonization or colonized means MRSA bacteria is carried on the patient or in the patient's nasal passages but he does not have any symptoms. MRSA in Healthcare Settings, supra note 11.

15. Klevens et al., supra note 12 , at 1765 . As opposed to community acquired-MRSA ("CA-MRSA"), defined as: "infections that are acquired by persons who have not been recently (within the past year) hospitalized or had a medical procedure (such as dialysis, surgery, catheters)." Richard P. Evans, The Silent Epidemic: CA-MRSA and HA-MRSA, 2 AM. ACAD. OF ORTHOPAEDIC SURGEONS Now, May 2008, at 2, available at http://www.aaos.org/news/aaosnow/may08/research1.asp. This note will not address CAMRSA, the definition is merely given to help the reader distinguish between HA-MRSA and CA-MRSA as currently classified.

16. Evans, supra note 15, at 2-3.

17. Mathieu Eveillard et al., Impact of Screening for MRSA Carriers at Hospital Admission on Risk-Adjusted Indicators According to the Imported MRSA Colonization Pressure, 59 J. OF HOSP. INFECTION 254, 256-57 (2005).

18. Jane D. Siegel et al., Management of MultidRug-Resistant Organisms in HealthCare Settings, 6 (Center for Disease Control and Prevention 2006) (2006), available at $\mathrm{http}: / / \mathrm{www} . c d c . g o v / \mathrm{ncidod} / \mathrm{dhqp} / \mathrm{pdf} / \mathrm{ar} / \mathrm{mdroGuideline2006.pdf.}$

19. Huletsky et al., supra note 10 , at 976.

20. Id. 
HA-MRSA by implementing effective preventative measures. ${ }^{21}$ Several Facilities have been successful in limiting the transmission of HA-MRSA by implementing procedures to reduce the spread of the infection. Detection of MRSA-positive or colonized patients at the time of Facility admission is the only way to implement isolation and contact precautions which will reduce the subsequent spread of HA-MRSA. ${ }^{22}$ Therefore, screening all patients upon Facility admission would greatly reduce the possibility that a MRSA-positive patient will come into contact with otherwise healthy patients. It is estimated that seventy to ninety percent of MRSA-colonized patients are not identified ${ }^{23}$ and without screening, more than half will remain undetected, ${ }^{24}$ increasing the likelihood of HA-MRSA transmission.

Since studies have shown that MRSA can be controlled by proper screening procedures and other preventative measures, Facilities face liability when a patient contracts HA-MRSA while in their care. The extent of Facility liability depends on the duty owed to the patient, the standard of care in other similar Facilities, whether there was a breach in the standard of care or duty, and the causal relationship between the breach of the standard of care or duty and the patient's injury. ${ }^{25}$

Currently, when a patient receives improper care while in a Facility he is eligible to bring a variety of tort claims against the Facility, including, negligence, medical malpractice, and vicarious liability. Therefore, a patient who contracts HA-MRSA from a Facility is able to bring a suit requesting compensation for damages suffered as a result of contracting the infection. HA-MRSA and other hospital-acquired infections were once considered an inevitable part of Facility care and Facilities billed for them accordingly, but with growing evidence that Facilities can take steps to reduce infections ${ }^{26}$ and new private insurance and Medicare/Medicaid policies that refuse to pay for hospital-acquired infections, Facilities face a greater risk of patient suits.

MRSA highlights a growing concern for the medical industry. Facilities struggle with numerous issues including: what duty, if any, is owed to patients, workers, or visitors when a MRSA-positive patient is in the care of a Facility; what is the standard of care for MRSA-positive patients; what

21. Id.

22. M. H. Wernitz et al., Effectiveness of a Hospital-Wide Selective Screening Programme for Methicillin-Resistant Staphylococcus aureus (MRSA) Carriers at Hospital Admission to Prevent Hospital-Acquired MRSA Infections, 11 EUR. SOC'Y OF ClinICAL MiCROBIOLOGY \& INFECTIOUS DISEASES 457, 457 (2005).

23. MCCAUGHEY, supra note 2, at 5.

24. Eveillard et al., supra note 17, at 257.

25. DAN B. DobBS, The LAW OF TORTS $269,631,633-34$, \& 668-70 (West Group 2nd reprint 2002) (2000); JAY M. ZITTER, CAUSES OF ACTION 2D 79 (24th ed., 2007), available at 24 COA.2d 79 (2007) (Westlaw).

26. Vanessa Fuhrmans, Insurers Stop Paying for Care Linked to Mistakes, THE WALL STREET JOURNAL, January 15, 2008, available at 1/15/08 APDATASTREAM 15:54:39 (Westlaw). 
duty, if any, exists to isolate MRSA-positive patients; what preventative measures are required to reduce the spread of MRSA; which patients should be screened for MRSA; is consent to screen required; and who should be billed for MRSA screening? Until the CDC or the medical industry implements national standards and procedures for handling MRSA, individual Facilities face liability when patients contract HA-MRSA.

This Note discusses lawsuits based on HA-MRSA, staph infections, and other diseases and the screening and preventative measures adopted by some Facilities that have successfully reduced HA-MRSA transmission. In order to facilitate a better understanding of why screening and preventative measures are necessary, Section II explains the background of MRSA, modes of MRSA transmission, and MRSA's growing resistance to all antibiotics. Section III weighs the importance of Facilities taking preventative measures and offers details regarding Medicare/Medicaid and private insurance policies' reduction of coverage for secondary infections. ${ }^{27}$ Section III also compares the cost of prevention to the cost of treating a MRSAinfected patient. Section IV introduces the various tort claims a patient who contracts HA-MRSA might bring, the extent of Facility liability, and recent legislation passed in several states requiring Facilities to test patients for MRSA.

\section{BACKGROUND}

\section{A. The History of MRSA}

In the last decade MRSA has become a healthcare concern for many individuals because it has reached significant numbers not only in healthcare settings, but in community settings as well. MRSA first became an issue in Facilities around the world in the $1960 \mathrm{~s},{ }^{28}$ and the United States reported its first MRSA infection in $1968 .^{29}$ Roughly 2.3 million Americans were colonized with MRSA in $2005,{ }^{30}$ and these numbers are increasing each year. The rate of hospital patients infected with MRSA increased from two percent in 1974; to forty percent in $1997 ;^{31}$ to sixty-four percent in 2003; and continues to increase each year. ${ }^{32}$ Annually, more than 126,000 MRSA-positive patients report to U.S. hospitals requiring treatment. ${ }^{33}$

27. This Note uses the terms "secondary infection," "hospital-acquired infection," "healthcare-acquired infection," and "nosocomial infection" interchangeably.

28. Klevens et al., supra note 12 , at 1764.

29. HR Series: Policies \& Practices, supra note 13.

30. Centers for Disease Control and Prevention, S. aureus and MRSA Surveillance Summary 2007 [hereinafter MRSA Surveillance 2007], http://www.cdc.gov/ncidod/ dhqp/ar_mrsa_surveillanceFS.html (last visited November 7, 2008).

31. HR Series: Policies \& Practices, supra note 13.

32. MCCAUGHEY, supra note 2 , at 1.

33. MRSA Surveillance 2007, supra note 30. 
In the United States, MRSA infections tripled from 2000 to 2005 and were ten times higher in 2005 than $1995 .{ }^{34}$ In 2005 , there were " 368,600 hospital admissions for MRSA-including 94,000 invasive infections[,] ${ }^{35}$ about eighty-six percent of which were healthcare-acquired. ${ }^{36}$ The CDC found that MRSA killed nearly 19,000 people in the United States in 2005, a number higher than victims of Hurricane Katrina and AIDS combined the same year. ${ }^{37}$ A survey preformed by the Association for Professionals in Infection Control and Epidemiology reported that forty-six of every 1,000 patients were infected with MRSA, meaning that 1.2 million hospitalized patients are infected with MRSA. ${ }^{38}$ With numbers like this, it is possible that MRSA is killing almost 120,000 patients a year. ${ }^{39}$ Due to the increasing number of MRSA infections in Facilities and the community, preventative measures must be taken to reduce its transmission.

\section{B. Transmission of MRSA}

MRSA is transmitted through direct skin-to-skin contact, contact with shared items or surfaces (such as towels, bandages, bedrails, privacy curtains, and gloves) that have come into contact with someone else's colonized or infected skin, and the failure of healthcare personnel to wash their hands between patient contacts. ${ }^{40}$ Healthcare workers and their failure to wash their hands, ${ }^{41}$ as well as person-to-person contact with individuals who have open draining wounds or are asymptomatic carriers, ${ }^{42}$ are the most common modes of transmission in Facilities. Bacteria survive on healthcare workers' hands after patient contact unless soap and water or an alcohol-based hand sanitizer is used. ${ }^{43}$ MRSA and other nosocomial infections pose the greatest risk in Facilities that fail to follow standard handwashing procedures. A healthcare worker's hands may become contaminated when she touches the skin of a MRSA-colonized or infected patient. ${ }^{44}$ The most common healthcare workers who fail to wash their hands between

34. Evans, supra note 15 , at 2 .

35. Id.

36. MRSA Surveillance 2007, supra note 30.

37. Evans, supra note 15, at 2.

38. Medical Errors and Patient Safety, [July 2008] Health Pol'y Tracking ServiceIssue Brief 080714.25 at p.5 (July 14, 2008).

39. Id.

40. See generally Glauser, supra note 3, at 1-3; see also A. Al-Hamad \& S. Maxwell, How Clean is Clean? Proposed Methods for Hospital Cleaning Assessment, J. OF HosP. INFECTION 1, 1-2 (2008), doi: 10.1016/j.jhin.2008.08.006.

41. MRSA in Healthcare Settings, supra note 11.

42. Glauser, supra note 3, at 7. Asymptomatic carriers are colonized with MRSA, which can be revealed by nasal swab testing. Id.

43. MRSA in Healthcare Settings, supra note 11.

44. Id. 
patient contacts are physicians. ${ }^{45}$ The first line of defense for Facilities should be to monitor healthcare workers for compliance with hand-washing procedures after contact with every patient. Healthcare workers also need to wash their hands after coming in contact with the environment of a patient who is either a MRSA-carrier or is MRSA-positive.

Studies have shown that MRSA can also contaminate the patient's environment. ${ }^{46}$ These studies found that almost three-fourths of patient rooms contained MRSA bacteria. ${ }^{47}$ MRSA has been found on door handles, furniture, equipment, patient charts, stethoscopes, gowns, clothes, room curtains, nurses' keyboards, and telephones. ${ }^{48}$ MRSA has the ability to survive on dry surfaces for weeks; including the surface of packaging for sterile goods for more than thirty-eight weeks. ${ }^{49}$ Therefore, touching a MRSAcontaminated environmental source, and then touching a patient, increases the likelihood that patients will acquire HA-MRSA. ${ }^{50}$ The environment where a MRSA-positive patient stayed while in the Facility needs to be thoroughly cleaned with an alcohol-based disinfectant after patient discharge. The nurses' station and equipment also need to be disinfected routinely to reduce transmission of MRSA. ${ }^{51}$ Facilities that have been successful in eliminating MRSA have: (1) implemented procedures requiring staff to wear disposable gowns when entering the rooms of patients carrying MRSA; (2) used disposable blood pressure cuffs; and (3) put strict cleaning procedures in place for equipment that came into contact with MRSApositive or MRSA-colonized patients. ${ }^{52}$ Due to MRSA's growing resistance to numerous antibiotics, it is imperative that Facilities take measures to reduce its transmission.

\section{MRSA Resistant To Almost All Antibiotics}

MRSA has developed resistance to almost every antibiotic used to treat it since 1968: "including synthetic variants of penicillin such as methicillin, cephalosporins, penems and carbapenems." resistance to the purely synthetic strain of antibiotics known as fluoroquinolones. $^{54}$ MRSA's resistance to ciprofloxaxin, a fluroquinolone, occurred in

45. Glauser, supra note 3 , at 1 .

46. Al-Hamad \& Maxwel, supra note 40 , at 2 .

47. MCCAUGHEY, supra note 2 , at 4.

48. See Al-Hamad \& Maxwell, supra note 40, at 5; see also MCCAUGHEY, supra note 2 , at 4.

49. Al-Hamad \& Maxwell, supra note 40 , at 5.

50. See id. at 1 .

51. See id.

52. MCCAUGHEY, supra note 2, at 6.

53. Eric Kades, Preserving a Precious Resource: Rationalizing the Use of Antibiotics, 99 Nw. U. L. REV. 611, 615 (2005).

54. Id. 
just one year. ${ }^{55}$ Very few antibiotics still work to treat MRSA, and the few "that may still work include vancomycin (Vancocin, Vancoled), trimethoprim-sulfamethoxazole (Bactrim, Bactrim DS, Septra, Septra DS), linezolid (Zyvox), tetracycline [(Terramycin)], or clindamycin [(Evoclin)]."56

Due to MRSA's ability to mutate and become resistant to most other antibiotics, vancomycin, has become the antibiotic of "last resort" for treatment of MRSA, however, even vancomycin has failed to be effective because some strains of MRSA are now exhibiting signs of resistance to it. $^{57}$ MRSA's resistance to drug treatment is a growing concern for the healthcare industry, because once MRSA becomes resistant to all antibiotics, Facilities will be unable to treat patients who have MRSA. Therefore, the only way to stop MRSA from becoming a "super bug" 58 is to implement other preventative measures in Facilities and reduce the reliance on treatment with antibiotics.

\section{Preventative Measures that Work AND NeW InSURANCE POLICIES PREVENTING COST-RECOVERY FOR SECONDARY INFECTIONS}

\section{A. Preventative Measures}

Several Facilities that have implemented procedures to reduce the spread of HA-MRSA have had success in limiting its transmission. Polymerase chain reaction ("PCR") tests have been developed that are able to test for MRSA and provide results in two to four hours and cost only twenty-five to thirty dollars per test. ${ }^{59}$ PCR testing is relatively inexpensive, and Facilities that implement PCR testing can isolate MRSA-colonized or positive patients within a few short hours. Other countries, and some Facilities in the United States, have eradicated transmission of HA-MRSA by adopting procedures to identify and isolate MRSA-positive patients on admission. $^{60}$ Facilities can keep HA-MRSA infection rates low or nonexistent

55. Id.

56. Healthline, Staphylococcal Diseases, http://www.healthline.com/ adamcontent/mrsa (last visited January 29, 2009).

57. Kades, supra note 53, at 615 (citation omitted).

58. Super bugs are antibiotic-resistant bacteria that are able to "outsmart antibiotics so that these medicines no longer work well." WEBMD, VANCOMYCIN-RESISTANT ENTEROCOCCI (VRE), http://www.webmd.com/a-to-z-guides/vancomycin-resistant-enterococci-vre-overview (last visited January 29, 2009).

59. United States General accountability Office, Health-Care-Associated INFECTIONS IN Hospitals, AN OVERVIEW of STATE REPORTING PROGRAMS AND INDIVIDUAL HOSPITAL INITIATIVES TO REDUCE CERTAIN INFECTIONS, GAO-08-808, at 8 (2008) [hereinafter STATE REPORTING OF HEALTH-CARE-ASSOCIATED INFECTIONS], available at $\mathrm{http} / / / \mathrm{www} . g a 0 . g 0 v /$ new.items/d08808.pdf. "PCR is a highly sensitive, molecular testing technique that detects MRSA-specific DNA." Id.

60. Id. 
with the implementation of MRSA-screening and other safety precautions. ${ }^{61}$ The programs that have been successful in limiting transmission of HAMRSA are based on early identification of MRSA-positive patients and subsequent isolation of those patients suspected of being or testing MRSApositive. $^{62}$

To reduce the risk of liability, Facilities need to enforce hand hygiene policies by monitoring staff and physicians for compliance and implementing punishment for policy violations. ${ }^{63}$ Facilities should also implement policies that require healthcare workers to wear gowns and gloves when contact with a potential MRSA-positive patient or equipment used on a MRSA-positive or colonized patient occurs. ${ }^{64}$ Some Facilities have implemented the use of signs at entrances of rooms containing MRSA-positive patients as a reminder to staff and visitors to follow all contact precautions. ${ }^{65}$ Facilities should disinfect equipment, such as door knobs, bedrails, telephones, and wheel chairs, between uses, make checklists to ensure housekeeping staff properly disinfect rooms when MRSA-positive or colonized patients are discharged, and change privacy curtains as ways to ensure the eradication of MRSA bacteria prior to placing new patients in the room. $^{66}$

Facilities should also flag patient charts if the patient has tested MRSA-positive and use techniques to identify the patient as having a former MRSA-positive culture in order to implement the same contact precautions upon readmission. ${ }^{67}$ The Facilities studied that implemented the precautions recommended above reduced HA-MRSA infection rates by fifty to seventy-four percent. ${ }^{68}$ The Facilities that reported increases in costs from implementing the preventative measures still reduced their overall costs because they were treating fewer patients with MRSA infections. ${ }^{69}$

One hospital in North Carolina screened all patients entering the hospital for MRSA. ${ }^{70}$ Within eight months, the North Carolina hospital had reduced its number of HA-MRSA infections by sixty percent. ${ }^{71}$ A Yaleaffiliated hospital in Connecticut reduced HA-MRSA infections by two-

61. See id.

62. Menno R. Vriens et al., Methicillin-Resistant Staphylococcus aureus Carriage Among Patients After Hospital Discharge, 26 INFECTION CONTROL AND HosP. EPIDEMIOLOGY 629, 629 (2005) (citations omitted), available at http://www.journals. uchicago.edu/doi/pdf/10.1086/502592.

63. See State RePORTING OF HeAlTh-CARE-AsSociated INFECTIONS, supra note 59, at 29.

64. See id. at 29-30.

65. See id. at 30.

66. $I d$.

67. Id.

68. Id. at 32 .

69. StATE REPORTING OF HEALTH-CARE-AsSOCIATED INFECTIONS, supra note 59, at 36.

70. Fuhrmans, supra note 26.

71. Id. 
thirds after implementing patient screening measures. ${ }^{72}$ A Boston hospital found that routine culturing of patients and implementation of contact precautions for MRSA patients resulted in a sixty-seven percent drop in infection rates. $^{73}$ The Boston hospital believed it would have reduced HAMRSA infection rates even more if it either isolated patients until results were received, or used the rapid PCR MRSA test, which produces results in a couple of hours, instead of the culture method, which produces results in two days. ${ }^{74}$ The University of Virginia hospital discovered that identifying every MRSA-positive and colonized patient by testing all patients and isolating those harboring MRSA bacteria enabled it to eliminate MRSA from the hospital after an outbreak, not only once, but twice. ${ }^{75}$

The United States Governmental Accountability Office ("GAO") sampled fourteen different hospitals that had implemented procedures to reduce the transmission of MRSA. ${ }^{76}$ The GAO discovered that, even though each hospital tested different patient populations and used various testing procedures, each Facility conducted routine MRSA-screening. ${ }^{77}$ Three of the fourteen hospitals tested every patient for MRSA, and the other eleven hospitals tested patients in adult or neonatal intensive care units. ${ }^{78}$ All fourteen hospitals implemented changes to the procedures for hand hygiene, and more than half of the hospitals increased contact precautions and improved their procedures for disinfecting environmental surfaces. ${ }^{79}$ After the implementation of preventative measures, each hospital reported a decline in the number of HA-MRSA infections. ${ }^{80}$ The GAO and other studies demonstrate that Facilities that not only test patients for MRSA, but also implement preventative measures to reduce its transmission are successful.

These studies also show that if Facilities are not testing patients, they have no idea which patients are MRSA-positive or colonized. These Facilities are capable of spreading MRSA simply by touching MRSA-positive or colonized patients and then touching MRSA-negative patients. One study found that twenty-four percent of patients with MRSA nasal colonization develop infections within one to forty-six days of having a positive screen. ${ }^{81}$ This study shows that colonized patients and patients who are already showing signs of MRSA infection pose the same health risk to MRSA-

72. MCCAUGHEY, supra note 2, at 9.

73. Id.

74. Id.

75. Id. at $12-13$.

76. StATE REPORTING OF HEAlth-CARE-AsSOCiATED INFECTIONS, supra note 59, at 5.

77. Id.

78. Id.

79. Id.

80. Id.

81. Adam Keene et al., Staphylococcus aureus Colonization and the Risk of Infection in the Critically Ill Patients, 26 INFECTION CONTROL AND HosP. EPIDEMIOLOGY 622, 624 (2005), available at http://www.journals.uchicago.edu/doi/pdf/10.1086/502591. 
negative patients. Based upon the GAO report and other studies that demonstrate the modes of MRSA transmission, Facilities should face liability when they fail to enact preventative measures to eliminate the spread of HA-MRSA.

\section{B. Medicare/Medicaid and Private Insurance Policies Forbidding Payment of Secondary Infections}

The Centers for Medicare and Medicaid Services ("CMS") announced in May, 2006 that it would no longer reimburse Facilities for costs associated with preventable errors. ${ }^{82}$ CMS' goal is to hold Facilities and providers responsible for errors in the hope that the quality of care will improve and there will be a decline in the number of medical errors. ${ }^{83}$ As of October 1, 2008, Facilities no longer receive additional payments based on the presence of a secondary infection caused by a "never event." only can Facilities not receive additional payments from CMS, CMS' policy prevents Facilities from passing the costs associated with "never events" on to patients. ${ }^{85}$ MRSA is currently classified as a nosocomial infection, and nosocomial infections associated with surgeries or indwelling ${ }^{86}$ catheters are listed as one of CMS" "never events."87 MRSA could also fall under the category of hospital-acquired Stapylococcus aureus bloodstream infections being added to the CMS' list of "never events" in $2009{ }^{88}$ It is also possible that MRSA could soon have its own listing on the CMS' list of "never events" because CMS evaluates and updates the list of "never events" annually. ${ }^{89}$ Many private insurance companies have followed

82. Sheryl Tatar Dasco \& Kathryn E. Higgins, The "Never" Events: What it Means for Physicians, 10 No. 3 J. Health CaRe Compliance 33, 33 (2008) (citations omitted).

83. Id.; but see Rachel Deutsch, The Federal Role in Reducing Hospital-Acquired Conditions: are Medicare Reimbursement Incentives Enough?, 42 ColuM. J.L. \& Soc. PROBS. 1 (2008).

84. A never event refers to an event that should never occur in the healthcare field. Tatar Dasco \& Higgins, supra note 82, at 33. (citations omitted). Examples of "never events" include: leaving a foreign object in a patient after surgery; medication errors, such as giving a patient the wrong medicine; giving a patient the wrong blood; performing surgery on the wrong body part; performing surgery on the wrong patient; and patient death from use of contaminated devices. $I d$. at 35 .

85. Id. at 34 (citations omitted).

86. Indwelling refers to the use of a tube in an "organ or passage to maintain drainage, prevent obstruction, or provide a route for administration of food or drugs." MERRIAMWEBSTER'S MEDICAL DICTIONARY http://medical.merriam-webster.com/medical/indwelling (last visited February 15, 2009).

87. Trisha Torrey, Learn More About Medicare's 2008 Never Events Policy There's More To It Than Just Patient Safety, http://patients.about.com/od/ patientempowermentissues/a/medicare08never.htm (last visited November 8, 2008); Torrey, supra note 1.

88. Centers for Medicare \& MEDICAId SERVICES OfFICE OF Public AFFaIRS, CMS Proposes to EXPAND Quality Program for InPATIENT SERvices IN FY 2009 (April 14, 2008), http://www.cms.hhs.gov/apps/media/press/release.asp?Counter=1863.

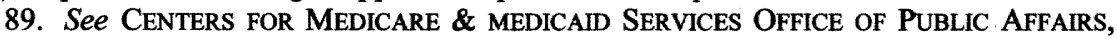


CMS' lead and are now refusing payment for secondary infections. ${ }^{90}$

Aetna and WellPoint, two of the largest private health insurers, have started incorporating CMS' policy into their contracts with Facilities. ${ }^{91}$ Aetna's new contracts specifically state that it will neither pay for, nor let Facilities bill patients for, an event that is on CMS' list of "never events."92 The idea behind CMS and private insurers' policies is to improve safety measures and make Facilities face liability for the costs associated with failing to implement procedural safeguards. ${ }^{93}$ If medical personnel followed all procedures they have been taught, Facilities could reduce hospital-acquired infection rates by almost ninety percent. ${ }^{94}$ In light of the CDC and Reduce Infection Deaths' ("RID") findings that patients develop nearly two million infections in hospitals each year, and over 100,000 deaths occur as a result of hospital-acquired infections, insurers have had to impose policies that shift the costs to the Facilities. ${ }^{95}$

RID found that hospital-acquired infections add $\$ 30.5$ billion in treatment costs each year. 96 The CDC also found that common "never events" add more than $\$ 4.5$ billion a year in treatment costs, and antibiotic-resistant bloodstream infections, such as MRSA, add as much as $\$ 100,000$ in treatment costs per patient. ${ }^{97}$ The added costs of treating secondary infections offer Facilities an incentive to implement procedures for reducing errors. ${ }^{98}$ A North Carolina hospital that implemented MRSA screening for every patient who entered the Facility found that private and public insurers were more than willing to pick up most of the cost for screening each patient if it meant reducing the costs associated with treating secondary infections. ${ }^{99}$ It cost the hospital approximately $\$ 1$ million to screen every patient who entered; however, insurers paid $\$ 800,000$ of the $\$ 1$ million and the hospital reduced HA-MRSA infections by sixty percent. ${ }^{100}$ The reduction in HAMRSA infections alone saved the hospital more than the $\$ 200,000$ cost associated with MRSA-screening. The hospital would have spent more than that to treat just a few patients who contracted HA-MRSA and would have been unable to recoup any of the money for the nosocomial infection from

INCORPORATING SELECTED NATIONAL QUALITY FoRUM AND NEVER EVENTS INTO MEIDCARES LIST OF HOSPITAL-ACQUIRED CONDITIONS (April 14, 2008), http://www.cms.hhs.gov/ apps/media/press/factsheet.asp?Counter $=3043$

90. Fuhrmans, supra note 26.

91. Id.

92. Id.

93. See id.

94. Margot Sanger-Katz, Accountability in Mind; Sisters Watched Their Mother Suffer from Infection in Hospital, CONCORD MONITOR, March 2, 2008, available at 2008 WLNR 5642653, at 4 (Westlaw 2008).

95. Fuhrmans, Insurers supra note 26; see also MCCAUGHEY, supra note 2, at i.

96. MCCAUGHEY, supra note 2, at i.

97. Fuhrmans, supra note 26.

98. Id.

99. Id.

100. Id. 
CMS, insurers, or patients.

\section{The Costs to Treat versus the Costs to Prevent MRSA}

Studies of United States hospitals have shown that in 1999 the cost to treat a MRSA infection was $\$ 27,083$ to $\$ 34,000$ per patient, and healthcare costs associated with MRSA treatment were around $\$ 6$ billion annually. ${ }^{101}$ In 2003 , "it cost $\$ 14.5$ billion to treat [MRSA] in [United States] hospitals." 102 Due to the increase in the number of MRSA cases in recent years, it is safe to assume the healthcare costs associated with MRSA treatment have risen. Facilities are rarely reimbursed for the added costs to treat a patient who contracts a secondary infection. ${ }^{103}$

For example, a Pittsburgh hospital that treated a patient for pancreatitis would have made a profit had the patient not contracted HA-MRSA; instead the hospital lost $\$ 41,813 .^{104}$ Patients who contract staph infections, including MRSA, increase hospital costs by more than three times the cost of treatment for their uninfected counterparts. ${ }^{105}$ MRSA infections can increase costs for routine surgeries to over $\$ 1$ million in a short amount of time ${ }^{106}$ and research shows it costs more to treat HA-MRSA infections than it would cost to implement a screening program. ${ }^{107}$

Another Pittsburgh Facility reduced HA-MRSA infections by ninety percent when it implemented MRSA-screening in its intensive care unit. ${ }^{108}$ The screening cost the Facility $\$ 35,000$, but prevented enough HA-MRSA infections to reduce Facility costs for treatment of those infections by $\$ 801,000 .^{109}$ Two Facilities in South Carolina that implemented targeted screening programs spent $\$ 113,955$ on the screening, but saved the Facilities $\$ 1,548,740$ in what would have been treatment costs for HA-MRSA infections had the screening not been done. ${ }^{110}$ Another Facility found that even adding in the costs for collecting samples, laboratory testing of samples, using barrier protection supplies, time spent taking protective measures, and isolation amounted to only $\$ 35,281$; an amount dwarfed by the $\$ 801,652$ to $\$ 2,015,919$ expected costs for treating HA-MRSA infec-

101. Ann Huletsky et al., supra note 10 , at 976 .

102. MCCAUGHEY, supra note 2 , at 25.

103. Id. at 21 .

104. Id.

105. Id. at 22 .

106. See Sanger-Katz, supra note 94 , at 4.

107. See MCCAUGHEY, supra note 2, at 23 . Facilities will argue that they are financially strapped now and requiring them to test all patients for HA-MRSA only increases their debt and may put them out of business. This is a weak argument because insurers are willing to pay for testing and it costs more to treat a MRSA infection than it does to pay for the costs associated with prevention. Fuhrmans, supra note 26.

108. MCCAUGHEY, supra note 2, at 23.

109. Id.

110. Id. 
tions. ${ }^{111}$ That Facility had an annual savings of $\$ 766,371$ to $\$ 1,980,638$ for HA-MRSA alone. ${ }^{112}$ Savings this significant indicate why CMS and private insurers' adopted policies holding Facilities responsible for the costs of secondary infections and "never events."

CMS and private insurers' new policies enhance a patient's chances of winning a negligence, medical malpractice, or vicarious liability suit for contracting HA-MRSA. By including MRSA in categories on its "never events" list, and possibly adding it as a separate "never event", CMS and private insurers are taking the position that Facilities have the ability to prevent patients from contracting HA-MRSA while in their care. While it is possible that some HA-MRSA infections may be unpreventable because a patient was tested and did not test MRSA-positive, it is rather unlikely. A Facility would still be subject to suit by the patient who contracted HAMRSA.

\section{ANALYSIS: WHY FACILITIES SHOULD BE HELD LIABLE UNDER ClAIMS OF NEGLIGENCE, MEDICAL MALPRACTICE, OR VICARIOUS LIABILITY}

\section{A. The Law in the United States}

Research has shown that HA-MRSA is preventable when recommended guidelines are followed and Facilities are no longer shielded from liability. ${ }^{113}$ Now, when a patient receives improper care from a Facility, he is eligible to bring a number of tort claims against the Facility. Contracting HA-MRSA should be considered improper Facility care since several accredited institutions have published recommended guidelines for the implementation of MRSA-testing and preventative measures. A patient who contracts HA-MRSA can bring tort claims for negligence, medical malpractice, and vicarious liability.

When a patient contracts an infection from a Facility the patient is required to prove three or four elements to succeed on a claim for the hospital-acquired infection. ${ }^{114}$ The patient must show:

(1) the standard of care applicable to the defendant [Facility] or its employees; (2) that the [Facility] breached such standard; [ ] (3) that a proximate causal relationship existed between the [Facility's] breach of duty and the injury suffered by the patient, either based on direct evidence, or under the doctrine of res

111. Id. at 24 .

112. Id.

113. Id. at 26.

114. ZITTER, supra note 25 . 
ipsa loquitur[; ${ }^{115}$ [and (4)] [i]f the action is based on the [Facility's] vicarious liability for the negligence of an employee, the plaintiff must also show the existence of a principal-agent relationship between the [Facility] and the employee sufficient to impose liability on the [Facility]. ${ }^{116}$

In most jurisdictions, in order for a patient to establish the standard of care required by the Facility, she will be required to provide medical expert testimony. ${ }^{117}$ The expert can show that the employee violated accepted standards of professional practice, and that the deviation from those standards was the cause of the patient's hospital-acquired infection. ${ }^{118}$ Professional standards arise not only from mandatory industry standards, but also from the voluntary undertaking of recommended regulations and policies. ${ }^{119}$ For example, a Facility that voluntarily undertakes the standards set out by the CDC, Society for Healthcare Epidemiology of America, Infectious Diseases Society of America, Institute for Healthcare Improvement, and Healthcare Infection Control and Prevention Advisory Committee (collectively, "Governing Agencies") for MRSA may have patients use those standards to show the Facility breached the appropriate duty of care. ${ }^{120}$ Patients will also argue that a Facility's failure to use the Governing Agencies' guidelines for reducing HA-MRSA infections by testing patients, taking isolation precautions, and implementing hand-washing procedures makes it liable to the patient under negligence, medical malpractice, or vicarious liability. ${ }^{121}$

The Facility undertakes the duty to provide a clean environment with sterile techniques and instruments as soon as a Facility-patient relationship

115. Res Ipsa Loquitur "means the thing speaks for itself. . . the plaintiff's injury and the immediate events surrounding it can by themselves show negligence, even though the plaintiff is unable to prove any specific act that was unreasonably dangerous." DOBBS, supra note 25 , at 370 .

116. ZITTER, supra note 25.

117. JaMes WALKeR SMITH, Hospital LiabiLITY § 4.03(1) (ALM Properties, Inc., Law Journal Press, a division of American Lawyer Media, Inc. 2008).

118. Id.

119. Id. Facilities will argue that screening all patients for MRSA is a voluntary undertaking they are not presently required to take because the $\mathrm{CDC}$ and other governing agencies in the medical community have not mandated MRSA-screening. Therefore, the voluntary undertaking would be increasing the applicable standard of care owed to patients and subjecting Facilities to liability they were not previously subject to. This argument will likely fail because multiple studies have shown that while the CDC and other governing agencies' do not mandate MRSA-screening or particular infection control practices for MRSA, the Facilities that implemented the recommended guidelines for MRSA-screening and infection control practices have reduced the spread of HA-MRSA. See generally MCCAUGHEY, supra note 2 .

120. SMITH, supra note 117.

121. See MCCAUGHEY, supra note 2, at 26. 
arises. $^{122}$ A Facility was once able to escape liability in negligence, medical malpractice, and vicarious liability cases if it could show that it was following the standard of care in the community; however, that defense is inadequate today since the guidelines for best practices are published and nationally available. ${ }^{123}$ Facilities will only escape liability if:

(1) the patient does not prove the appropriate standard of care; (2) the [Facility] and its employees exercised reasonable care in preventing the patient's contraction of an infection; (3) the conduct of the [Facility] or its employees was not the proximate cause of the patient's infection; (4) no inference of negligence was available under res ipsa loquitur; [and] (5) in an action based on vicarious liability, it was not shown that the allegedly negligent caregiver was the agent of the [Facility].

Therefore, a Facility that fails to follow, or has an employee breach, the recommended standards of care set out by the Governing Agencies faces increased chances for being held liable by a court when a patient contracts HA-MRSA or another healthcare-acquired infection. The patient, who contracts HA-MRSA, or another healthcare-acquired infection, has the greatest chance of succeeding on a claim for negligence.

\section{Negligence}

Patients who contract HA-MRSA must prove five elements to establish a prima facie case of negligence against the Facility. ${ }^{125}$ First, the patient must show that the Facility owed her a duty of care. ${ }^{126}$ Second, that the Facility breached its duty by its conduct. ${ }^{127}$ Third, that the Facility's conduct in fact caused harm to the patient. ${ }^{128}$ Fourth, that the Facility's conduct was not only a cause in fact of the patient's harm, but was also a proximate cause. ${ }^{129}$ Fifth, that the patient suffered damages in a definable amount, "based on actual harm of a legally recognized kind such as physi-

122. James Walker Smith, Hospital Liability $\S 7.02$ (ALM Properties, Inc., Law Journal Press, a division of American Lawyer Media, Inc. 2008).

123. See MCCAUGHEY, supra note 2, at 26.

124. ZITTER, supra note 25 .

125. DoBBS, supra note 25, at 269.

126. Id.

127. Id.

128. $I d$.

129. Id. Proximate cause means "that the [facility's] conduct is perceived to have a significant relationship to the harm suffered by the [patient]." Id. 
cal injury to" the patient. ${ }^{130}$

A patient need only establish the elements of negligence by proof or persuasion to establish a prima facie case against a Facility. ${ }^{131}$ Patients in the past may have faced difficulty in establishing that the Facility owed them a duty of care because the healthcare industry had not implemented standards for dealing with MRSA. Since recent studies have shown that Facilities that implement preventative screening measures reduce the transmission of HA-MRSA, patients should now be able to show that Facilities have the duty to implement preventative measures, including patient screening, or face liability.

Facilities can be held liable for negligence by their employees ${ }^{132}$ under the doctrine of corporate negligence. ${ }^{133}$ In cases where a patient acquires HA-MRSA, it is likely the patient will sue the Facility because the particular employee at fault may prove difficult to discover and the employees usually do not have the ability to pay large judgments like the Facility does. Corporate negligence requires the Facility to exercise reasonable care for patient safety by maintaining a safe environment, only hiring and retaining physicians who are competent, monitoring all personnel practicing medicine regarding care of patients, and adopting and enforcing procedures and policies that provide safe and quality care for patients. ${ }^{134}$ Facilities, therefore, can, and should, be held liable in negligence for failure to take the necessary precautions to protect patients from acquiring HA-MRSA. A patient who contracts HA-MRSA only has to prove that the Facility breached the duty of care to him by failing to practice proper hygiene, take preventative measures, diagnose MRSA infection, etc.

In Kapuschinsky v. United States, a Facility was found liable for negligence when a premature baby in a neonatal intensive care unit contracted staph, and tests of the nursery staff revealed that one nurse was positive for staph. ${ }^{135}$ The Facility was held negligent because it permitted the nurse to work in the neonatal intensive care unit and premature nursery prior to having the nurse submit to a nose or throat culture or physical exam. ${ }^{136}$ The Facility's negligence arose when it permitted the nurse to work with infants with compromised immune systems without testing her, knowing the nurse

130. DoBBs, supra note 25, at 269.

131. Id.

132. Kapuschinsky v. United States, 248 F. Supp. 732, 735 (D. S.C., 1966) (quoting 96 A.L.R.2d 1205, 1207).

133. The doctrine of corporate negligence "creates a nondelegable duty which the [Facility] owes directly to a patient. ... [and] an injured party does not have to rely on and establish the negligence of a third party. . . [ [It] arises from the policies, action, or inaction of the [Facility] itself, rather than the specific acts of individual [Facility] employees." Gahm v. Thomas Jefferson University Hospital, 2000 WL 233247, 2 (E.D.Pa., 2000).

134. Id.

135. Kapuschinsky, 248 F. Supp. at 734-35.

136. Id. at 737 . 
had previously worked in various hospital wards, including a pediatrics clinic taking care of both sick and well children. ${ }^{137}$ The court combined circumstantial evidence to find that the infant was infected with staph bacteria and that the only way the infant could have been infected was by the nurse who tested positive for staph. ${ }^{138}$ Strains of staph can be the same even though they appear resistant to different antibiotics, "because when the organism 'passes from one individual who is a carrier, to a second individual who develops a clinical infection, -- the organism frequently becomes resistant to more antibiotics.",139 A Facility breaches its duty to a patient when it permits a nurse, who previously worked in a ward with MRSAinfected patients, to come into contact with infection-susceptible patients without giving the nurse a physical exam or testing for drug-resistant bacteria colonization or infection. ${ }^{140}$

In negligence actions, a Facility is liable if it fails to meet the national standards specified by the Joint Commission on Accreditation of Hospitals or other similar accredited standards by other accredited bodies for other Facilities of its kind. ${ }^{141}$

Conformity with the standard of care observed by other [Facilities] in good standing in the same community cannot necessarily in itself be availed of as a defense in a negligence action where criterion relied upon is shown to constitute negligence, in that it fails to guard against injuries to the patient in failure to meet standards of care self imposed or established. ${ }^{142}$

To relieve a member of the medical profession from liability for injury to a patient on the ground that he followed a degree or standard of care practiced by others in the same locality is ... unthinkable when the degree or standard of care in question is shown to constitute negligence because it fails to meet the test of reasonable care and diligence required by the med-

137. Id. at 748 (citation omitted).

138. Id. at $742-43$.

139. Id. at 743. This case and Note are not suggesting that all Facility employees must be tested for MRSA after contact with every MRSA-colonized or MRSA-positive patient, they are merely stating that Facility employees who care for patients colonized or infected with MRSA should be tested prior to working in an area of the Facility that cares for immuno-compromised patients.

140. See id.

141. See Kapuschinsky v. United States, 248 F. Supp. 732,744 (D. S.C., 1966) (citing Duling v. Bluefield Sanitarium, Inc. 142 S.E.2d 754, 765 (W. Va. 1965)).

142. Id. at 747 (citation omitted). 
ical profession. ${ }^{143}$

Known precautions for the safety of patients must be taken, despite what other Facilities are doing. ${ }^{144}$ Negligence law has established that there is a greater need for caution when the danger is more probable. ${ }^{145}$ HA-MRSA should not be treated differently than the staph infection in Kapuschinsky, and Facilities should be held liable for the failure to test healthcare workers and other patients entering the Facility for colonization or infection with MRSA.

Similarly, in Helman v. Sacred Heart Hospital, the court found the Facility liable for Helman's contraction of staph while in defendant's Facility and the jury awarded Helman damages totaling $\$ 67,839.97 .^{146} \mathrm{Hel}$ man's roommate complained of a boil under his arm and the next day drainage was apparent; however the roommate was not transferred out of Helman's room and into isolation until four days later. ${ }^{147}$ Nurses and attendants taking care of both Helman and his roommate "moved from one patient to the other, changed sheets, gave sponge baths, changed dressings, administered back rubs, and in general, carried out the necessary hospital routine for the care of the two men[,]" without observing the Facility's sterile techniques when infection was suspected. ${ }^{148}$ The nurses failed to wash their hands or leave the room between contacts with Helman and his roommate. ${ }^{149}$ The day that Helman's roommate was placed in isolation for having tested positive for staph, Helman's surgical site began draining the same type of discharge as his former roommate's boil and a culture confirmed Helman had staph. ${ }^{150}$ The jury found that enough circumstantial evidence existed to confirm the nurses and attendants infected Helman with staph from his roommate. ${ }^{151}$

In Maldonado v. Sinai Medical Group, Inc., Maldonado alleged negligence against his physicians for failure to diagnose a bone infection, which left him a paraplegic. ${ }^{152}$ The court found that while Maldonado was being treated for a staph infection, physicians failed to investigate a CAT scan after Maldonado complained of back and abdominal pain. ${ }^{153}$ Medical expert testimony revealed that the deterioration in Maldonado's spine was

143. Id. (citation omitted).

144. See id. (citation omitted).

145. Id. at 748 (citation omitted).

146. Helman v. Sacred Heart Hospital, 381 P.2d 605, 606 (Wash. 1963).

147. Id. at 606-07.

148. Id. at 606.

149. Id. at 606-07.

150. Id. at 607 .

151. See id. at 611.

152. Maldonado v. Sinai Medical Group, Inc., 2008 WL 161671, slip op. at 2-3 (N.D. Ill. 2008).

153. Id. at 3. 
consistent with osteomyelitis which correlated with the back and abdominal pain and had it been diagnosed sooner, Maldonado could have avoided paralysis. ${ }^{154}$

In Kimberly F. v. Mary Hitchcock Memorial Hospital, the Facility was found liable for negligence and medical malpractice when Kimberly F. contracted genital herpes while in the Facility giving birth. ${ }^{155}$ Kimberly F. was placed in a room with a patient who had genital herpes and healthcare workers, in caring for both patients, failed to wash their hands between patient contacts. ${ }^{156}$ The Facility was held liable because it admitted a patient known to have genital herpes, took that patient off of infection precautions, and placed her in a room with Kimberly F. while she was still exhibiting symptoms of an active infection. ${ }^{157}$ This case demonstrates the failure of healthcare workers to observe standard hand-washing procedures when a patient was known to be infected with an incurable disease. MRSA is more contagious and fatal than genital herpes, and Facilities owe patients the duty to abide by standard procedures for treatment and recommended guidelines for handling MRSA infections.

Two other cases settled based on negligent acts by Facilities. The first Facility reached an $\$ 825,000$ settlement with a plaintiff who alleged his father's leg amputation, and later death from an HA-MRSA bloodstream infection, was caused by negligent care given while in the Facility. ${ }^{158}$ The second Facility entered a $\$ 3,815,000$ settlement for negligent care of a patient who suffered from a decubitus ulcer and resulting MRSA infection and later died from pneumonia. ${ }^{159}$ The Facility failed to treat the decubitus ulcer for nineteen days and failed to notify physicians; thus, allowing the MRSA infection to spread to the bone. ${ }^{160}$ One hospital in Florida has been sued by thirteen separate patients claiming he contracted HA-MRSA from the Facility while there for surgery. ${ }^{161}$

Recent cases and settlements show that Facilities are facing liability for negligence when a patient contracts MRSA, staph, or another hospitalacquired infection while in their care. It appears that it would be more cost effective for Facilities to implement preventative measures and monitor healthcare workers for compliance in order to eliminate the spread of drugresistant organisms than it would be to continue paying damages based on findings of liability.

154. Id. at 2-3.

155. Kimberly F. v. Mary Hitchcock Memorial Hospital, 1993 WL 498026, 1-2 (1st Cir., 1993).

156. Id.

157. Id. at 3-5.

158. Moore v. West Oaks Geriatrics Center, 2005 WL 3690831 (D. Tex. 2005).

159. Smith v. Senior Living Properties, LLC, 2002 WL 32155086 (D. Tex. 2002).

160. Id.

161. MCCAUGHeY, supra note 2, at 27. 


\section{Medical Malpractice}

Causes of action for medical malpractice require the patient to prove the same five elements of negligence, plus a sixth element: a failure of the physician to meet "the standard of care of other professionals in the same field." 162 This standard is referred to as the professional-peer standard. ${ }^{163}$ The trier of fact must determine if the physician's conduct conformed to the medical standards or customs in the community in which the physician practices. ${ }^{164}$ Courts usually require the patient to establish the professional standard using expert testimony. ${ }^{165}$ Medical experts testify whether the procedure is medically acceptable in the physician's community, and if the procedure is acceptable, if it is considered the medical standard. ${ }^{166}$

A patient who contracts HA-MRSA will have a more difficult time proving medical malpractice than negligence. The malpractice case is more difficult because the Governing Agencies have currently only recommended guidelines regarding standards to be used for MRSA and have yet to require mandatory practices. However, some HA-MRSA cases have succeeded on medical malpractice claims.

The New Jersey Superior Court, Appellate Division, in Colucci v. Oppenheim, found that the trial court erred when it found that Colucci did not have a cause of action for medical malpractice because the trial judge improperly excluded plaintiff's counsel from drawing inferences for the jury. ${ }^{167}$ Colucci developed a MRSA infection at his surgery site and the treating doctor referred to it as a low-grade infection. ${ }^{168} \mathrm{~A}$ few days later, Colucci reported to the hospital and his infection was diagnosed as MRSA. ${ }^{169}$ The MRSA infection spread throughout Colucci's body and he went into a coma, suffered from brain abscesses, lung problems, heart murmurs, blood infection, kidney failure, and spinal abscesses. ${ }^{170}$ Colucci's claim for medical malpractice stated that the treating physician who performed his initial surgery deviated from the accepted standard of care by performing the particular surgery on Colucci despite Colucci's background and susceptibility to infection. ${ }^{171}$ The physician also deviated in the standard of care for treatment after surgery regarding the pin sites that later be-

162. DoBBs, supra note 25 , at 631 (citations omitted).

163. Id.

164. Id. at 633.

165. Id. (citation omitted).

166. Id. at 633-34. 1999).

167. See Colucci v. Oppenheim, 740 A.2d 1101, 1108-09 (N.J. Super. Ct. App. Div.

168. See id. at 1105.

169. See id.

170. Id.

171. See id. 
came infected. ${ }^{172}$ Colucci was granted a new trial on his claim for medical malpractice.

Medical malpractice cannot be shown unless the patient can point to specific acts or omissions by the Facility, or physician, for the harm suffered. ${ }^{173}$ A patient is required to show more than just MRSA's presence in the Facility, she must show that some act or omission by the Facility or physician was the cause of her injury in order to be awarded damages. ${ }^{174}$ In Crist v. Dean, even though Crist contracted HA-MRSA from St. Vincent hospital, the source of the HA-MRSA infection was unknown because Crist had never been tested to see if she carried the infection, the skin graft was not tested prior to its use, and none of the staff were tested. ${ }^{175}$ To succeed in a malpractice claim there must be some evidence to determine the source of the infection. ${ }^{176}$ Had Crist demonstrated the source of her HA-MRSA infection, she might have succeeded on her malpractice claim. Just like Crist, many patients who contract HA-MRSA are suing for medical malpractice, increasing the number of medical malpractice claims being filed.

The City of Philadelphia has more than double the national median for malpractice case filings, and "plaintiffs prevail in $44 \%$ of verdicts . . . with $24 \%$ of awarded verdicts in excess of $\$ 1$ million." "177 MRSA was responsible for forty-five of the 154 cases brought by plaintiffs in Philadelphia. ${ }^{178}$ It is easier for a patient to show that a Facility failed to adhere to the standards of care when a patient contracts HA-MRSA because HA-MRSA is considered a preventable secondary infection. ${ }^{179}$ Facilities are more prone to medical malpractice suits now that studies have demonstrated that one-third of healthcare-acquired infections are preventable by implementing infection control programs. ${ }^{180}$ The forty-five Philadelphia HA-MRSA cases for malpractice were surgeries performed on "clean body site[s] (i.e., knees, sternum) and these areas should have the lowest incidence of preventable

172. See id. at 1105.

173. See Crist v. Dean, 2007 WL 266444, slip op. at 5 (Ark. App. 2007).

174. See id. at 6.

175. See id. at 1-2.

176. See id.

177. John L. Guinan et al., A Descriptive Review of Malpractice Claims for Health Care-Acquired Infections in Philadelphia, 33 AM. J. OF INFECTION CONTROL 310, 310 (2005), available at http://ovidsp.tx.ovid.com.proxy.ulib.iupui.edu/spa/ovidweb.cgi? WebLinkFrameset $=1 \& S=$ OAFDFPJJDHDDIONKMCGLIDNKINFIAA00\&returnUrl $=\quad h t t p \% 3 a \% 2 \mathrm{f} \%$ 2fovidsp.tx.ovid.com\%2fspa\%2fovidweb.cgi\%3f\%26Full\%2bText\%3dL\%257cS.sh. 15.16 .1 $8.40 \% 257 \mathrm{c} 0 \% 257 \mathrm{c} 00000545-200506000-00011 \% 26 \mathrm{~S} \% 3 \mathrm{dOAFDFPJJDHDDIONKMC}$ GLIDNKINFIAA00\&directlink=http $\% 3 \mathrm{a} \% 2 \mathrm{f} \% 2$ fgraphics.tx.ovid.com $\% 2$ fovftpdfs $\% 2$ fFPD DMCNKIDNKDH00\%2ffs 046\%2fovft\%2flive\%2fgv023\%2f00000545\%2f00000545200506000-00011.pdf\&filename $=\mathrm{A}+$ descriptive + review + of + malpractice+claims + for + health+care-acquired+infections+in+Philadelphia.

178. Id.

179. Id.

180. Id. 
[healthcare-acquired infections]." ${ }^{\text {"181 }}$ Poor compliance with basic hand hygiene is assumed in nearly fifty percent of the malpractice cases when MRSA and other infections transmitted by direct contact with contaminated hands are indicated. ${ }^{182}$ Malpractice cases also arise where a physician fails to diagnose MRSA.

In Bindhammer v. Cubelli, Bindhammer brought a medical malpractice action against the physician for failure to obtain a deep wound culture and to recommend an infectious disease consult at the first sign of infection to determine whether MRSA was the causative agent. ${ }^{183}$ Two months later, Bindhammer's MRSA infection was discovered and he subsequently underwent fifteen more surgeries to treat the infection. ${ }^{184}$ Malpractice was found and Bindhammer received a jury verdict for damages of $\$ 1.6$ million. ${ }^{185}$

In another malpractice case, a jury awarded $\$ 2.58$ million to a retiree who acquired a staph infection and lost his right leg, part of his left foot, a kidney, and some hearing. ${ }^{186}$ Another hospital settled for $\$ 815,000$, and the nursing home settled for $\$ 130,000$, in a case brought by a patient who contracted HA-MRSA causing him to have an amputation of his right leg below-the-knee and to have a calcanectomy ${ }^{187}$ of his left foot. ${ }^{188}$ In another case, a physician settled a medical malpractice claim for $\$ 2.2$ million because he failed to properly treat the plaintiff's husband for a MRSA infection. ${ }^{189}$ The physician discharged the plaintiff's husband twenty-three hours after surgery while he was suffering from a fever, pain, and an elevated white blood cell count, which a few days later resulted in a MRSA infection draining into the husband's abdomen subsequently causing his death. ${ }^{190}$

It appears that patients who bring medical malpractice cases for HAMRSA or staph succeed just as often as those patients who bring negligence cases. The growing trend indicates that Facilities either settle, or juries find in favor of patients who contracted HA-MRSA. Juries are finding that Facilities have a duty to prevent transmission of HA-MRSA and are awarding compensation accordingly. Facilities should implement procedures and

181. Id.

182. Id.

183. Bindhammer v. Cubelli, 2007 WL 3101672, slip op. at 1-2 (N.J. Super. Ct. App. Div. 2007).

184. Id. at 1.

185. Id. at 3 .

186. William C. Lhotka, $\$ 2.58$ Million Awarded in Suit, ST. Louis Post-DisPATCH, July 31, 2008, available at 2008 WLNR 14240517, at 1 (Westlaw 2008).

187. Calcanectomy refers to an incision or sectioning of the calcaneus (heel) bone. See MERRIAM-WEBSTER'S MEDICAL DICTIONARY http://medical.merriam-webster.com/ medical/calcaneus (last visited February 1, 2009); see MIRIAM-WEBSTER's MEDICAL DICTIONARY http://medical.merriam-webster.com/dictionary/tomy.

188. Reilly v. Augustana Nursing Home, 2007 WL 4976276 (N.Y. Sup. 2007).

189. Dos Santos v. Zarif, 2003 WL 23221495 (Conn. Super. Ct. 2003).

190. Id. 
infection control practices to reduce liability for hospital-acquired infections. ${ }^{191}$

\section{Vicarious Liability}

Facilities can be held liable for the negligent acts of their employees, if those acts are committed within the scope of employment. ${ }^{192}$ Vicarious liability permits a patient to recover against both the Facility and the doctor or nurse for damages when she contracts HA-MRSA. ${ }^{193}$ Vicarious liability exists because the doctor or nurse is not only acting on his or her own behalf, but as an employee of the Facility. ${ }^{194}$ Courts have begun to recognize that a Facility owes patients a non-delegable duty of care and thus causes harm to patients when it fails "to provide appropriate services, equipment, and staff support, or in negligently selecting, training, reviewing, or supervising physicians who are permitted to use the [Facility's] resources.",195

In Frigo v. Silver Cross Hospital and Medical Center, the Facility was found negligent for failing to require a physician to go through a surgery residency before operating on patients. ${ }^{196}$ Frigo suffered a staph infection in her foot after Dr. Kirchner operated on it. ${ }^{197}$ The infection progressed and Frigo's foot had to be amputated; hence, she brought suit against Silver Cross Hospital and Medical Center and Dr. Kirchner for negligence, malpractice, and breach of duty. ${ }^{198}$ Frigo was awarded $\$ 7,775,668.02$ by a jury against Silver Cross and Dr. Kirchner settled before trial for $\$ 900,000{ }^{199}$ The hospital was held liable for the negligent acts of Dr. Kirchner in failing to monitor and treat Frigo's foot infection in the proper manner because:

[A]s a matter of public policy,... [Facilities] are in the best position to protect their patients and, consequently, have an independent duty to select and retain competent independent physicians seeking staff privi-

191. Facilities will argue that implementing procedures and infection control practices for MRSA without national mandates is undertaking a new duty, not previously owed to the patient that adds costs to an already struggling healthcare system. The increased costs could detrimentally affect the inpatient healthcare delivery system that is already in financial crisis due to low reimbursement rates and care for the indigent, a crisis that is dramatically increasing with the failing economy. Nevertheless, Facilities that have implemented procedures and infection control practices for MRSA have not appeared to incur substantial costs; therefore, the Facilities' argument is weak.

192. DoBBS, supra note 25 , at 668 (citations omitted).

193. DoBBS, supra note 25 , at 669 (citations omitted).

194. Id. (citations omitted).

195. Id. at 670 (citations omitted).

196. Frigo v. Silver Cross Hospital and Medical Center, 876 N.E.2d 697, $702-3$ (IIl. App. Ct. 2007).

197. Id.

198. Id.

199. Id. 
leges.... [T] he [Facility's] liability extends only to the physician's conduct while rendering treatment to patients in the [Facility] and does not extend to his conduct beyond the [Facility's] premises.... [T] he [Facility] will only be responsible for the negligence of an independent physician when it has failed to exercise due care in the selection and retention of that physician on its staff. ${ }^{200}$

The jury held the Facility liable for Frigo's injuries because Frigo's experts established that Dr. Kirchner lacked surgery experience and failed to treat Frigo's ulcer and infection properly. ${ }^{201}$ Had the Facility not granted Dr. Kirchner surgery privileges, Frigo's foot amputation would not have occurred. ${ }^{202}$ The court found proximate cause between the Facility's negligence in giving Dr. Kirchner surgery privileges without following the bylaws and credentialing requirements and Frigo's amputation sufficient to uphold the jury's findings. ${ }^{203}$

In Maldonado, the plaintiff tried to hold the Facility vicariously liable for the actions of its physicians in negligently failing to diagnose his bone infection. ${ }^{204}$ The court found vicarious liability for the Facility did not exist because Maldonado failed to produce evidence to show that the Facility was negligent in its performance of managerial or administrative functions. ${ }^{205}$ In contrast, the Facility in Kimberly F. was held vicariously liable for the healthcare workers' failure to follow isolation precautions, the physician releasing the infected patient from isolation precautions, and the nurse's failure to relay to the physician the infected patient's active infection. ${ }^{206}$

Not much case law exists mentioning a Facility's vicarious liability for the actions of nurses or physicians. It is safe to assume, however, that when a Facility is found liable due to healthcare workers' failure to follow hand-washing procedures, isolation precautions, and other standards of care, that the court is relying on vicarious liability or the doctrine of corporate negligence. Vicarious liability is possible when the Facility has a standard of care or policy regarding safe practices to reduce the spread of MRSA and other infections, and the physician or nurse fails to follow the standard of care or policy. Vicarious liability can also arise when a Facility

200. Id. at 721-22 (citations omitted).

201. Id. at 726 .

202. Frigo v. Silver Cross Hospital and Medical Center, 876 N.E.2d 697, 726 (Ill. App.

Ct. 2007).

203. Id.

204. Maldonado v. Sinai Medical Group, Inc., 2008 WL 161671, slip op. at 6-7 (N.D. Ill. 2008).

205. Id.

206. Kimberly F. v. Mary Hitchcock Memorial Hospital, 1993 WL 498026, 1-2 (1st Cir., 1993). 
does not have a standard of care or policy set out regarding safe practices for reducing the spread of MRSA and other infections.

Verdicts in negligence, medical malpractice, and vicarious liability cases involving HA-MRSA appear to be quite costly to Facilities. If Facilities implemented preventative measures and patient-screening on admission for MRSA, they would reduce their liability and cut costs for treating HAMRSA infections. Several state legislatures have taken the position that Facilities should be held liable and have enacted legislation requiring Facilities to test patients for MRSA.

\section{B. Recent Legislation}

Due to the increase in MRSA infections over the last eight years, several states have proposed or adopted legislation requiring Facilities to take more proactive measures to reduce transmission of MRSA. ${ }^{207}$ Facilities claim they should not be mandated to implement screening measures because each Facility has implemented their own program to handle healthcare-acquired infections, but legislators are not listening to the Facilities. ${ }^{208}$ The legislators are more concerned with the public demand for more aggressive approaches that reduce the spread of HA-MRSA, especially in light of the CDC's findings that six out of seven patients with a MRSA infection contracted it from a Facility. ${ }^{209}$ Four states, in 2007, enacted legislation requiring Facilities to screen for MRSA, eight states considered similar legislation in 2008 , and a few other states have proposed similar legislation for the 2009 session. $^{210}$

\section{Pennsylvania}

In 2007, Pennsylvania became the first state to mandate Facility reporting of all healthcare-acquired infections to the State Council. ${ }^{211}$ The State Council is required to issue a public report identifying the number of patients infected with healthcare-acquired infections by Facility name. ${ }^{212}$ Pennsylvania's state legislature also enacted legislation requiring Facilities to test all high-risk patients for MRSA and other drug-resistant bacteria. ${ }^{213}$ Despite these regulations, Facilities must also test employees who have had

207. Kevin B. O'Reilly, States Consider Requiring Hospitals to Screen for MRSA, AM. MED. NEwS, February 16, 2009, available at http://www.ama-assn.org/amednews/2009/02/ 16/prsb0216.htm.

208. Id.

209. Id.

210. Id.

211. Medical Errors and Patient Safety [Year-End 2007], Health Pol'y Tracking Service-Issue Brief 080107.6 at p. 2 (January 7, 2008) [hereinafter Issue Brief 080107.6].

212. Id. at 2-3.; 40 PA. Cons. STAT. $\$ 1303.404$ (2007).

213. Issue Brief 080107.6, supra note 211 , at 4 . 
contact with contagious patients, use a patient infection-tracking system, and establish and implement state-approved infection control practices. ${ }^{214}$ Facilities are not increasing operating expenses by testing all high-risk patients and employees for MRSA because the legislature also enacted legislation compelling insurers and medical assistance programs to reimburse Facilities for healthcare-acquired infection screening. ${ }^{215}$ Starting in 2009, Pennsylvania began rewarding quality improvement payments to Facilities that complied with enacted mandates and reduced healthcare-acquired infection rates by ten percent in the preceding year. ${ }^{216}$

\section{California}

The California legislature enacted legislation requiring all Facilities to report adverse events within five days to the Department of Health. Services and if the event is a threat to patient safety, welfare, or health, it must be reported within twenty-four hours. ${ }^{217}$ MRSA is likely to be classified as an adverse event if a patient contracts HA-MRSA while being treated for another condition in the Facility and would be required to be reported in five days. MRSA will also be classified as a threat to patient safety, health, and welfare if a patient reports to the Facility and tests positive within the first forty-eight hours of admission, requiring the Facility to report the MRSA infection within twenty-four hours to the Department of Health Services.

California also enacted legislation in 2007 requiring Facilities to test patients for MRSA within twenty-four hours if: (1) the patient is susceptible to infection and is having inpatient surgery; (2) the patient was discharged from a Facility within the previous thirty days; (3) the patient is being placed in the burn or intensive care unit; or (4) the patient receives dialysis. $^{218}$ Facilities are also required to implement infection control procedures and to appoint an infection control officer who ensures that MRSAtesting and reporting are carried out. ${ }^{219}$ Infection control procedures require, at a minimum, proper disinfection of all patient rooms, nursing stations, and other environmental sources where MRSA bacteria may be present. ${ }^{220}$ Facilities must also provide oral and written instructions to all patients who test MRSA-positive regarding the care needed to treat

214. Id.; 40 PA. Cons. STAT. $\S 1303.403$ (a) (2007); 40 PA. Cons. STAT. $§ 1303.404(\mathrm{e}-\mathrm{f})$ (2007). Section 1303.403(a)(4) specifically requires Facilities to identify patients colonized or infected with MRSA upon Facility admission.

215. 40 PA. CONS. STAT. $\$ 1303.406$ (2007).

216. 40 PA. Cons. STAT. $\$ 1303.407$ (2007).

217. Issue Brief 080107.6, supra note 211, at 3; CAL. HEALTH \& SAFETY CODE $§ 1279.1$ (2007). Adverse events include most of the CMS' list of "never events."

218. CAL. Health \& SAFETY CODE $\$ 1255.8(5)(\mathrm{b})(1)(\mathrm{A}-\mathrm{E})$ (2007).

219. CAL. HeAlTH \& SAFETY CODE $§ 1255.8(5)(\mathrm{f})(2007)$.

220. CAL. HEALTH \& SAFETY CODE § 1255.8(5)(e)(2)(2007). 
MRSA. $^{221}$

\section{New Jersey}

The New Jersey legislature enacted legislation requiring Facilities to use routine screening for MRSA as a matter of public health and to incorporate best practices as recommended by the Governing Agencies of the medical community. ${ }^{222}$ The Facilities are required, at first, only to implement the infection control practices in high-risk areas such as surgical units, or intensive care units, but the Facility must expand the infection control practices to the entire Facility as quickly as possible. ${ }^{223}$ Eventually, the Facilities should be testing all patients upon admission for MRSA, have contact precautions in place, and report the number of cases of HA-MRSA to the Department of Health. ${ }^{224}$

\section{Illinois}

The Illinois legislature enacted legislation requiring all Facilities to implement MRSA control practices that test all high-risk patients for MRSA upon admission. ${ }^{25}$ The Facilities must maintain records and report all cases of MRSA to the Department of Health for publication in the Hospital Report Card. ${ }^{226}$ All patients that test MRSA-positive are required to be isolated and hand-washing procedures must be followed. ${ }^{227}$ Illinois Facilities must also follow the guidelines set out by the CDC for MRSA and other drug-resistant organisms. ${ }^{228}$

\section{Tennessee}

The Tennessee legislature requires all Facilities to perform a risk assessment for MRSA in each Facility. Those Facilities that have not seen a reduction in cases of HA-MRSA must implement a statutorily required infection control program. ${ }^{229}$ The MRSA control programs should include

221. Cal. Health \& SAFETy CoDE $\S 1255.8(5)(d)(2007)$.

222. N.J. REV. STAT. § 26:2H-12.35 (2007).

223. N.J. REV. STAT. § 26:2H-12.36 (2007).

224. $\S 26: 2 \mathrm{H}-12.36$.

225. 210 ILl. COMP. STAT. 83/5 (2007); 210 Ill. Comp. Stat. 83/6.23 (2007).

226. 210 Ill. COMP. STAT. 83/5 (2007); 210 Ill. CoMP. STAT. 83/10 (2007). The Hospital Report Card is a report necessitated by The Hospital Report Card Act which requires all Illinois Facilities to prepare a quarterly report that details the hours worked by all nurses each day and how many covered each Facility area, all infection control procedures, and the number of MRSA or other bloodstream infections treated or discovered in critical care units to the State Department of Health. 210 ILL. COMP. STAT. 86/25 (2007).

227. 210 ILl. COMP. STAT. $83 / 5$ (2007).

228. 210 ILl. COMP. STAT. 83/6.23 (2007).

229. TENN. CODE ANN. § 68-11-269 (West 2009). 
employee and patient education, testing of all high-risk patients, contact precautions, increased hand-washing procedures, and intra-facility communication regarding the status of MRSA-positive patients being transferred. $^{230}$

\section{New Hampshire, Indiana, District of Columbia, Virginia, and Texas}

New Hampshire statutes require Facilities to follow the recommendations of the medical community's Governing Agencies and implement MRSA-testing for all patients, isolation of MRSA infected or colonized patients, and hand-washing and environmental source disinfection procedures. $^{231}$ Indiana law currently requires Facilities to report error rates to the State Department of Health. ${ }^{232}$ During the 2009 Indiana Legislative Session, a bill was introduced that would require Facilities to develop infection control programs to reduce HA-MRSA and submit annual reports on the number of MRSA infections in the Facility to the State Department of Health. $^{233}$ Similarly, the District of Columbia municipal regulations require Facilities to report the number of patients with MRSA infections, test all patients at high-risk for MRSA, and disclose the number of MRSAoutbreaks in the Facility. ${ }^{234}$. The District of Columbia also requires each Facility to have written infection control practices, identify all MRSAcolonized or infected patients in high-risk units, isolate all MRSA-infected or colonized patients, chart identification of all patients with prior MRSA infection, provide employee and patient education as to MRSAtransmission, and implement and enforce hand-washing policies. ${ }^{235}$

The Virginia legislature enacted legislation requiring all lab directors to report MRSA infections to the State Department of Health within three days. $^{236}$ Similarly, Texas statutes require labs to report all cases of MRSA to the program director. ${ }^{237}$ The Texas legislature also enacted legislation requiring the Health and Human Service Commission to research and implement programs for reporting MRSA in all Facilities. ${ }^{238}$

Based upon state legislatures' reactions to the recent epidemic of

230. $\S 68-11-269(\mathrm{~b})-(\mathrm{c})$.

231. N.H. CODE R. DEP'T. HeAlth \& HUM. SERVices $\S \S 301.04$ to 301.05 (Weil) (June $13,2008)$.

232. Issue Brief 080107.6, supra note 211 , at 3 .

233. H.B. 1539, 116th Gen. Assem., 1st Reg. Sess. (Ind. 2009), available at $\mathrm{http} / /$ www.in.gov/apps/lsa/session/billwatch/billinfo?year=2009\&session=1\&request=getBi $11 \&$ doctype $=H B \&$ docno=1539 (last visited March 9, 2009).

234. 22 D.C. CODE MUN. REGS. \$ 207.1-207.3 (Weil 2009).

235. 22 D.C. Code MUN. Regs. $\S 2038.1$ to 2038.7 (Weil 2009); 22 D.C. CODE MUN. REGS. $§ 3267.1$ to 3267.7 (Weil 2009).

236. Healthcare Providers and Facilities Snapshot, [November 2007] Health Pol'y Tracking Service-Snapshot 071128.3 at p. 7 (November 28, 2007) (citation omitted).

237. TeX. Health \& SAFETy CODE ANN. $\$ 81.0445$ (2007).

238. § 81.0445. 
MRSA, it appears that Facilities will soon be required to test, at a minimum, high-risk patients for MRSA upon Facility admission. Facilities will also be required to report all cases of MRSA in or presented to them to State Agencies. Without implementing the preventative measures published nationally and found to be effective by many studies, state legislation is forcing Facilities to face liability with the potential for large verdicts against the Facilities.

\section{CONCLUSION}

MRSA infections greatly increase treatment costs, and in recent years Facilities have seen an increase in liability to patients who contract HAMRSA. A Facility's failure to implement the recommended best practices for handling MRSA should make it liable to any patient who subsequently contracts HA-MRSA. Facilities owe patients a duty of care to keep patients safe from HA-MRSA, and should be required to test all patients upon admission. Testing patients is not unreasonable due to the development of PCR tests that can determine a patient's MRSA-status within two hours at a relatively low cost. Studies have shown that Facilities that have eradicated the spread of HA-MRSA have implemented procedures for identifying and isolating MRSA-colonized and MRSA-positive patients, strict cleaning practices, and other strict policies for healthcare workers to follow when treating MRSA-infected patients.

Facilities can decrease the risk of liability by enforcing hand hygiene policies, monitoring healthcare workers for compliance, implementing punishment for violations of the policy, and requiring healthcare workers to wear gowns and gloves when contact with potential MRSA-positive patients or equipment used on MRSA-positive patients occurs. Facilities should also disinfect equipment and rooms with alcohol-based disinfectants between uses, make checklists to ensure housekeeping staff properly disinfect rooms when MRSA-positive patients are discharged, and change privacy curtains as ways of ensuring eradication of MRSA bacteria. Facilities should also have measures for flagging patient charts if the patient has tested MRSA-positive in the past so that staff can implement the same contact precautions upon readmission.

The implementation by CMS and private insurers of policies that refuse to pay for, or let patients be billed for, "never events" provides Facilities more of an incentive to implement recommended precautions to prevent HA-MRSA infections, or they will be left absorbing the costs of treatment. Facilities that do not implement safety precautions to guard against HA-MRSA face the possibility of an increased number of patient lawsuits and larger verdicts against them based on the increase in patient awards over the last five years in HA-MRSA cases. Patient screening for MRSA is a duty of care owed to all MRSA-negative patients entering a Facility. If Facilities fail to screen, the consequences can be fatal; therefore, 
Facility liability for the failure to take relatively inexpensive recommended precautions is warranted. 
